\title{
NILAI DAN TIPE KONSUMEN RUMAH TANGGA DAN KAITANNYA DENGAN PERILAKU PEMBELIAN PRODUK MAKANAN KEMASAN
}

\author{
Ani Ruwani ${ }^{1}$, Retnaningsih $\left.{ }^{1 *}\right)$, Megawati Simanjuntak ${ }^{1}$ \\ ${ }^{1}$ Departemen Ilmu Keluarga dan Kosumen, Fakultas Ekologi Manusia, Institut Pertanian Bogor, \\ Bogor 16680, Indonesia \\ *) E-mail: lunafisa@yahoo.com
}

\begin{abstract}
Abstrak
Karakteristik konsumen memegang peranan penting dalam menentukan keputusannya dalam sebuah proses pembelian, termasuk di dalamnya nilai yang diyakini dan tipe konsumen. Penelitian ini bertujuan untuk melihat pengaruh nilai dan tipe konsumen rumah tangga terhadap perilaku pembelian makanan kemasan di wilayah perkotaan dan perdesaan Bogor. Desain penelitian yang digunakan adalah cross sectional. Contoh penelitian melibatkan 80 rumah tangga yang mengonsumsi makanan kemasan yang dipilih secara random sampling di lokasi studi yang ditentukan. Hasil penelitian menunjukkan bahwa rumah tangga di perkotaan memiliki nilai konsumen yang lebih baik daripada di perdesaan $(p<0,01)$. Tipe konsumen di perkotaan dan perdesaan lebih dari separuhnya termasuk dalam kategori konsumen aktif dan perilaku pembelian rumah tangga di perkotaan lebih tinggi daripada rumah tangga di perdesaan. Selain itu, terdapat hubungan yang signifikan antara nilai konsumen, tipe konsumen dan perilaku pembelian makanan kemasan. Faktor yang memengaruhi perilaku pembelian makanan kemasan diantaranya usia, lama pendidikan ibu rumah tangga, besar keluarga serta pendapatan keluarga.
\end{abstract}

Kata kunci: makanan kemasan, nilai, perilaku pembelian, tipe konsumen

\section{Values and Type of Households and Its Relationship to Purchasing Behavior of Packaged Foods}

\begin{abstract}
Characteristics of consumers play an important role in determining the purchasing decision process, including the value and type of consumers. The purpose of this study was to analyze the effects of values and type of households on purchasing behavior of packaged foods in rural and urban areas of Bogor. This research used cross sectional design and involved 80 households who consumed packaged food; selected by random sampling at chosen study site. The result of the study revealed that households in urban area had better value of consumer than in rural area $(p<0,01)$. Most of consumer both in urban and rural areas categorized as type of active consumer. The purchasing behavior in urban households was found higher than urban ones. Moreover, the research found a significant correlation among value of consumer, type of consumer, and purchasing behavior of packaged foods. Age of consumer, length of wife's education, family size, and family income influenced significantly on purchasing behavior of packaged foods in rural and urban areas.
\end{abstract}

Keywords: packaged foods, purchasing behavior, type of consumers, values

\section{PENDAHULUAN}

Manusia memiliki beberapa kebutuhan yang harus dipenuhi dalam hidupnya. Salah satu kebutuhan yang mendasar manusia adalah kebutuhan fisiologis. Terpenuhinya kebutuhan tertentu (terutama kebutuhan fisiologis) akan membuat konsekuensi pada diri individu untuk berusaha memenuhi kebutuhan lain yang lebih tinggi tingkatnya. Individu berusaha untuk dapat memenuhi kebutuhan fisiologisnya terutama makan dan minum daripada kebutuhan lainnya. Kebutuhan akan makan tersebut dapat dipenuhi dengan adanya produk makanan.

Kemajuan teknologi pengolahan makanan dan pengemasan saat ini mendorong banyak produsen untuk memproduksi produk makanan dengan cara dikemas atau biasa disebut dengan produk pangan kemasan. Produk pangan kemasan banyak dipilih konsumen karena dianggap lebih praktis dan mudah didapatkan. Contoh produk makanan kemasan 
diantaranya adalah mi instan, produk susu dan olahannya, makanan bayi, makanan ringan ataupun makanan kaleng.

Salah satu konsumen produk makanan kemasan adalah keluarga. Dalam hal ini, ibu rumah tangga secara umum akan bertanggung jawab dalam hal menentukan konsumsi pangan anggota keluarga. Menurut BPS (2011), konsumsi rumah tangga dibagi menjadi dua yaitu konsumsi pangan dan nonpangan. Bila dilihat berdasarkan letak geografis, wilayah perkotaan dan perdesaan di Indonesia khususnya di Bogor memiliki perbedaan dalam hal konsumsi rumah tangga per kapita. Data menunjukkan bahwa rata-rata konsumsi per kapita di kabupaten Bogor adalah Rp319.237 per bulan, sedangkan di Kota Bogor adalah Rp328.775 per bulan.

Nilai sangat erat kaitannya pada tingkah laku konsumen. Nilai memberikan arah pada sikap, keyakinan dan tingkah laku, serta memberi pedoman untuk memilih tingkah laku yang diinginkan oleh setiap individu itu sendiri. Tetapi, manusia tidak lahir dengan nilai yang tetap, nilai akan terbentuk dalam proses sosialisasi, dan transmisi melalui edukasi atau penurunan dari pengalaman generasi sebelumnya, grup sosial, atau dari individu ke individu. Peran utama dalam proses ini adalah adanya sosialisasi dari keluarga, institusi pendidikan dan agama, media massa, dan pemerintah (Kaze, 2010). Penelitian menunjukkan bahwa nilai memiliki hubungan yang erat dengan teori adaptasi sosial serta sebagai salah satu faktor yang dapat memprediksi perilaku konsumen dan kegiatan yang terkait dengan konsumen (Homer \& Kahle, 1998). Seorang ibu rumah tangga sebagai konsumen akan memiliki nilai yang terbentuk dari proses-proses tersebut. Oleh karena itu, nilai yang terbentuk akan menjadi pedoman dalam tingkah laku pembelian produk makanan kemasan.

Konsumen dapat digolongkan dalam beberapa tipe yang menjadi ciri khas setiap individu. Penggolongan tipe konsumen ini dapat berupa konsumen aktif dan konsumen pasif dalam pencarian informasi mengenai produk dan haknya sebagai konsumen. Nilai dan tipe konsumen ini akan menjadi ciri khas yang membedakan setiap individu dalam perilaku pembelian makanan kemasan di perdesaan dan perkotaan. Perilaku pembelian adalah tindakan yang dilakukan dalam pembelian barang dan jasa, seperti tempat pembelian, waktu terakhir pembelian, jumlah barang dalam pembelian, frekuensi pembelian, dan alokasi uang yang dikeluarkan (Sumarwan, 2011).

Penelitian sebelumnya mengenai nilai konsumen salah satunya adalah penelitian yang dilakukan oleh Kim et al. (2002) yang menemukan bahwa nilai self directed (self respect, being well respect, kebahagiaan) pada responden di China berhubungan dengan kebutuhan eksperimental (kebaruan, perubahan, trendi). Hal ini dapat membuat konsumen lebih banyak menghabiskan uang untuk berbelanja. Dalam hal tipe konsumen, penelitian Roos dan Gufftafson (2011) menemukan bahwa tipe konsumen pasif lebih cepat merespon terhadap sesuatu.

Saat ini, belum banyak penelitian dalam hal tersebut yang dilakukan di Indonesia, sehingga penelitian ini penting untuk dilakukan. Berdasarkan pemaparan tersebut, penelitian ini bertujuan untuk menganalisis nilai konsumen, tipe konsumen, dan perilaku pembelian produk makanan kemasan oleh rumah tangga di perdesaan dan perkotaan.

\section{METODE}

Desain penelitian yang digunakan adalah cross sectional. Pemilihan lokasi dilakukan secara purposive yaitu di Kota dan Kabupaten Bogor. Pemilihan kecamatan, kelurahan, RW dan RT dilakukan secara random sampling yaitu kelurahan Katulampa, Kecamatan Bogor Timur sebagai perwakilan perkotaan dan Desa Cibatok 1, Kecamatan Cibungbulang sebagai perwakilan wilayah perdesaan.

Populasi penelitian ini adalah seluruh keluarga lengkap yang membeli dan mengonsumsi makanan kemasan minimal tiga bulan terakhir. Contoh penelitian ini adalah rumah tangga di perkotaan dan perdesaan wilayah Bogor dengan jumlah masing-masing 40 rumah tangga, sehingga total contoh dari kedua wilayah adalah 80 rumah tangga. Teknik pengambilan contoh yang digunakan adalah random sampling. Responden penelitian ini yaitu ibu rumah tangga.

Data primer diperoleh dari wawancara dengan alat bantu kuesioner yang meliputi karakteristik keluarga, nilai konsumen, tipe konsumen, dan perilaku pembelian rumah tangga. Karakteristik keluarga yang diteliti terdiri atas usia, besar keluarga, lama pendidikan, lokasi geografis (perdesaan dan perkotaan), pendapatan total keluarga, dan pengeluaran total keluarga. 
Pengukuran nilai konsumen diukur dengan instrumen List of Value (LOV) yang dimodifikasi. Instrumen ini terdiri atas dimensi pemenuhan diri dan rasa aman dengan nilai Cronbach's alpha sebesar 0,608. Instrumen terdiri atas 13 pertanyaan dengan pilihan jawaban yaitu STS= "sangat tidak setuju", TS= "tidak setuju", $\mathrm{S}=$ "setuju" dan $\mathrm{SS}=$ "sangat setuju". Nilai konsumen dihitung berdasarkan hasil transformasi skor komposit dari penjumlahan skor pada variabel nilai konsumen menjadi nilai indeks. Selanjutnya, berdasarkan indeks, nilai konsumen dikategorikan menjadi tiga kategori yaitu kurang (indeks $<60$ ), sedang (indeks 6080 ), dan baik (indeks>80).

Pengukuran tipe konsumen menggunakan alat ukur yang dimodifikasi dari empat tipe pemberdayaan konsumen McGregor (2010) yaitu tipe informasi, perlindungan, dan advokasi konsumen, tipe kritik individual untuk kepentingan diri sendiri, tipe pendekatan kritis untuk diri sendiri, serta tipe pendekatan pemberdayaan untuk kepentingan mutual. Kuesioner terdiri atas 11 pertanyaan dengan jawaban menggunakan skala Likert, yaitu: STS= "sangat tidak setuju", TS= "tidak setuju", $\mathrm{S}=$ "setuju" dan SS= "sangat setuju". Kuesioner ini memiliki nilai Cronbach's alpha sebesar 0,706 . Tipe konsumen dikategorikan berdasarkan hirachial cluster menjadi dua tipe yaitu konsumen pasif dan aktif.

Perilaku pembelian makanan kemasan merupakan perilaku konsumen dalam membeli makanan kemasan per bulannya yang terdiri atas jenis makanan kemasan yang dibeli, frekuensi pembelian, waktu pembelian, pelaku pembelian, kebiasaan menyimpan, perencanaan pembelian, pertimbangan merk, ketertarikan pada makanan kemasan dan pengeluaran untuk makanan kemasan. Pengukuran perilaku pembelian konsumen dilakukan dengan mengisi kuesioner oleh responden pada pembelian makanan kemasan selama sebulan terakhir.

Data yang diperoleh kemudian diolah dan dianalisis secara deskriptif dan inferensial. Analisis deskriptif untuk menggambarkan karakteristik responden, karakteristik keluarga, dan perilaku pembelian konsumen. Perbedaan nilai konsumen dan perilaku pembelian di perdesaan dan perkotaan dianalisis menggunakan uji beda independent sample t-test. Untuk menganalisis hubungan antarvariabel yang diteliti dilakukan uji korelasi Pearson. Uji regresi linear berganda dilakukan untuk melihat faktorfaktor yang memengaruhi perilaku pembelian produk makanan kemasan. Uji regresi logistik digunakan untuk melihat faktor-faktor yang memengaruhi tipe konsumen. Pada variabel tipe konsumen, digunakan uji hirachial cluster untuk mengelompokkan ke dalam beberapa tipe yaitu tipe konsumen aktif dan konsumen pasif.

\section{HASIL}

\section{Karakteristik Responden dan Keluarga}

Berdasarkan karakteristik keluarga responden, rata-rata besar keluarga responden di perkotaan maupun di perdesaan tergolong kategori keluarga kecil ( $\leq 4$ orang). Rata-rata usia responden di perkotaan lebih dari 40 tahun, sedangkan rata-rata usia responden di perdesaan kurang dari 40 tahun. Rata-rata lama pendidikan responden di perdesaan adalah kurang dari 9 tahun, sedangkan ratarata lama pendidikan responden di perkotaan adalah lebih dari 9 tahun. Rata-rata lama pendidikan suami di perkotaan adalah lebih dari 9 tahun, sedangkan rata-rata lama pendidikan suami di perdesaan kurang dari 9 tahun. Hasil uji beda independent sample t-test antara wilayah perdesaan dan perkotaan menunjukkan terdapat perbedaan yang signifikan pada pendidikan suami dan istri, pendapatan keluarga dan pengeluaran keluarga per bulan. Rata-rata dan uji beda karakteristik keluarga disajikan dalam Tabel 1.

Tabel 1 Rata-rata dan uji beda karakteristik keluarga

\begin{tabular}{|c|c|c|c|}
\hline Variabel & $\begin{array}{c}\text { Perkotaan } \\
(\mathrm{n}=40)\end{array}$ & $\begin{array}{c}\text { Perdesaan } \\
(n=40)\end{array}$ & $\begin{array}{c}p- \\
\text { value }\end{array}$ \\
\hline $\begin{array}{l}\text { Besar } \\
\text { keluarga } \\
\text { (orang) }\end{array}$ & $4,10 \pm 1,26$ & $4,05 \pm 1,28$ & 0,861 \\
\hline $\begin{array}{l}\text { Usia suami } \\
\text { (tahun) }\end{array}$ & $\begin{array}{r}46,38 \pm 10,2 \\
8\end{array}$ & $\begin{array}{r}43,33 \pm 13,0 \\
8\end{array}$ & 0,250 \\
\hline $\begin{array}{l}\text { Usia istri } \\
\text { (tahun) }\end{array}$ & $\begin{array}{r}42,28 \pm 11,1 \\
0\end{array}$ & $\begin{array}{r}38,55 \pm 11,7 \\
7\end{array}$ & 0,149 \\
\hline $\begin{array}{l}\text { Lama } \\
\text { pendidikan } \\
\text { suami } \\
\text { (tahun) }\end{array}$ & $14,40 \pm 3,14$ & $7,50 \pm 2,80$ & $0,000^{*}$ \\
\hline $\begin{array}{l}\text { Lama } \\
\text { pendidikan } \\
\text { istri (tahun) }\end{array}$ & $\begin{array}{r}12,23 \pm 2,9 \\
8\end{array}$ & $6,50 \pm 1,90$ & $0,000^{*}$ \\
\hline $\begin{array}{l}\text { Pendapatan } \\
\text { keluarga } \\
\text { (Rp/kapita/b } \\
\text { ulan) }\end{array}$ & $\begin{array}{r}1.11 \mathrm{E} 6 \pm 5 \\
91 \mathrm{E} 5\end{array}$ & $\begin{array}{r}376.761 \pm 3 . \\
33 E 5\end{array}$ & $0,000^{*}$ \\
\hline $\begin{array}{l}\text { Pengeluara } \\
\text { n keluarga } \\
\text { (Rp/kapita/ } \\
\text { bulan) }\end{array}$ & $\begin{array}{r}681.299 \pm 4 \\
.16 \mathrm{E} 5\end{array}$ & $\begin{array}{r}301.458 \pm 2 . \\
02 E 5\end{array}$ & $0,000^{*}$ \\
\hline
\end{tabular}




\section{Nilai Konsumen}

Nilai merupakan kepercayaan atau segala sesuatu yang dianggap penting oleh seseorang atau suatu masyarakat (Sumarwan, 2011). Pada penelitian ini, nilai dibagi dalam dua dimensi yaitu pemenuhan diri dan rasa aman. Pada dimensi pemenuhan diri, sebesar 62,5 persen rumah tangga di perkotaan pada kategori sedang dan sebesar 52,5 persen rumah tangga di perdesaan berada pada kategori kurang. Pada dimensi rasa aman, sebagian besar $(80,0 \%)$ rumah tangga di perkotaan tergolong pada kategori sedang, sedangkan lebih dari separuh $(55,0 \%)$ rumah tangga di perdesaan tergolong pada kategori kurang. Hasil uji beda menunjukkan bahwa secara keseluruhan, nilai konsumen rumah tangga di perdesaan dan perkotaan memiliki perbedaan yang signifikan. Sebaran, nilai ratarata, standar deviasi, dan koefisien uji beda untuk nilai konsumen berdasarkan lokasi geografis (wilayah perkotaan dan wilayah perdesaan) disajikan pada Tabel 2.

Tabel 2 Sebaran, nilai rata-rata, standar deviasi, dan koefisien uji beda untuk nilai konsumen berdasarkan lokasi geografis

\begin{tabular}{|c|c|c|c|c|}
\hline \multirow{3}{*}{$\begin{array}{l}\text { Kategori nilai } \\
\text { konsumen }\end{array}$} & \multicolumn{4}{|c|}{ Lokasi geografis } \\
\hline & \multicolumn{2}{|c|}{ Perkotaan } & \multicolumn{2}{|c|}{ Perdesaan } \\
\hline & $\mathrm{n}$ & $\%$ & $\mathrm{n}$ & $\%$ \\
\hline \multicolumn{5}{|l|}{ Pemenuhan diri } \\
\hline Kurang & 15 & 37,5 & 21 & 52,5 \\
\hline Sedang & 25 & 62,5 & 19 & 45,0 \\
\hline Baik & 0 & 0,0 & 1 & 2,5 \\
\hline Total & 40 & 100,0 & 40 & 100,0 \\
\hline $\begin{array}{l}\text { Rata-rata } \pm \\
\text { Standar deviasi }\end{array}$ & \multicolumn{2}{|c|}{$62,02 \pm 8,60$} & \multicolumn{2}{|c|}{$60,47 \pm 9,16$} \\
\hline$p$-value & \multicolumn{4}{|c|}{0,483} \\
\hline \multicolumn{5}{|l|}{ Rasa Aman } \\
\hline Kurang & 6 & 15,0 & 22 & 55,0 \\
\hline Sedang & 32 & 80,0 & 18 & 45,0 \\
\hline Baik & 2 & 5,0 & 0 & 0,0 \\
\hline Total & 40 & 100,0 & 40 & 100,0 \\
\hline $\begin{array}{l}\text { Rata-rata } \pm \\
\text { Standar deviasi }\end{array}$ & \multicolumn{2}{|c|}{$64,72 \pm 7,91$} & \multirow{2}{*}{\multicolumn{2}{|c|}{$57,63 \pm 9,63$}} \\
\hline$p$-value & & 0,0 & & \\
\hline \multicolumn{5}{|l|}{ Nilai total } \\
\hline Kurang & 14 & 35,0 & 20 & 50,0 \\
\hline Sedang & 26 & 65,0 & 20 & 50,0 \\
\hline Baik & 0 & 0,0 & 0 & 0,0 \\
\hline Total & 40 & 100,0 & 40 & 100,0 \\
\hline $\begin{array}{l}\text { Rata-rata } \pm \\
\text { Standar deviasi }\end{array}$ & \multicolumn{2}{|c|}{$63,27 \pm 6,83$} & \multirow{2}{*}{\multicolumn{2}{|c|}{$59,16 \pm 5,58$}} \\
\hline$p$-value & \multicolumn{2}{|c|}{$0,008^{* *}$} & & \\
\hline
\end{tabular}

Berdasarkan hasil yang disajikan pada Tabel 2, diketahui bahwa tidak ada perbedaan yang signifikan antara rumah tangga di wilayah perkotaan dan perdesaan pada dimensi pemenuhan diri. Hal ini berarti rumah tangga di wilayah perkotaan maupun di perdesaan merasa bahwa terpenuhinya kebutuhan pangan tidak hanya didapatkan melalui makanan kemasan, namun peran makanan nonkemasan juga dianggap penting. Berdasarkan data BPS (2011) di Indonesia, rata-rata konsumsi per kapita per bulan makanan nonkemasan seperti padi-padian, daging, ikan dan sayur-sayuran adalah sebesar Rp106.250,00, sedangkan untuk konsumsi makanan atau minuman jadi adalah sebesar Rp81.470,00 per kapita per bulannya.

Pada dimensi rasa aman, rumah tangga di wilayah perkotaan memiliki nilai yang lebih baik dibandingkan dengan rumah tangga di perdesaan. Rumah tangga di wilayah perkotaan memiliki keamanan pangan yang lebih baik daripada rumah tangga di perdesaan. Adanya rasa keamanan pangan yang lebih baik, membuat rumah tangga akan melihat beberapa hal yang membuat makanan kemasan tersebut layak untuk dikonsumsi, seperti mengecek tanggal kadaluarsa sebelum pembelian, melihat label halal pada kemasan ataupun memperhatikan kandungan yang terdapat dalam makanan kemasan tersebut. Humayun dan Hasnu (2009) menyebutkan bahwa dalam pembelian produk susu, konsumen memiliki keinginan untuk membeli produk makanan yang berkualitas dan berharap untuk menjadi sehat dalam hidupnya.

\section{Tipe Konsumen}

Pada penelitian ini, tipe konsumen ibu rumah tangga dikelompokkan dengan hirarchial cluster yang mengelompokkan responden ke dalam klaster yang memiliki kemiripan. Hasil penelitian menunjukkan bahwa sebesar 75,0 persen ibu rumah tangga di wilayah perdesaan dan 92,5 persen ibu rumah tangga di wilayah perkotaan tergolong pada konsumen aktif. Hasil uji beda $t$-test menunjukkan bahwa terdapat perbedaan yang signifikan $(p<0,01)$ antara tipe konsumen di wilayah perdesaan dan perkotaan. Tipe konsumen aktif merupakan konsumen yang aktif dalam mencari informasi terkait produk ataupun mencari informasi mengenai hak-hak dan kewajibanya sebagai konsumen. Konsumen aktif juga senantiasa memperjuangkan hak-haknya apabila ada kecurangan oleh pedagang. 


\section{Perilaku Pembelian Makanan Kemasan}

Jenis makanan kemasan yang dibeli. Perilaku pembelian makanan kemasan dapat dilihat dari jenis makanan kemasan yang dibeli oleh rumah tangga. Hampir seluruh (97,0\%) rumah tangga di perkotaan membeli produk susu dan olahannya setiap bulan. Begitu juga dengan pembelian makanan ringan, hampir seluruh $(90,0 \%)$ rumah tangga melakukan pembelian produk tersebut. Sebagian besar $(85,0 \%)$ rumah tangga di perdesaan membeli produk susu begitu pula dengan pembelian makanan ringan. Seluruh $(100,0 \%)$ rumah tangga di perdesaan dan perkotaan membeli mi instan setiap bulannya. Tabel 3 menunjukkan bahwa rumah tangga di perkotaan dan perdesaan yang melakukan pembelian produk makanan bayi dan makanan kaleng masih kurang. Oleh karena itu, selanjutnya hanya dipilih tiga jenis makanan kemasan yaitu produk susu dan olahannya, makanan ringan, dan mi instan untuk diolah lebih lanjut. Sebaran jenis makanan kemasan yang dikonsumsi oleh rumah tangga di wilayah perkotaan dan perdesaan disajikan pada Tabel 3 .

\section{Frekuensi pembelian makanan} kemasan. Hampir seluruh $(92,5 \%)$ rumah tangga di perkotaan membeli produk susu dan olahannya antara 1-15 kali per bulan, sedangkan hampir dua pertiga $(65,0 \%)$ rumah tangga di perdesaan membeli produk susu dan olahannya pada selang waktu tersebut. Pada produk makanan ringan, sebagian besar $(82,5 \%)$ rumah tangga di perkotaan membeli sekali sampai lima belas kali per bulannya, sedangkan di perdesaan sekitar dua pertiga $(65,0 \%)$ rumah tangga membeli pada selang frekuensi yang sama. Hasil uji beda menunjukkan antara rumah tangga di perdesaan dan perkotaan hanya berbeda signifikan pada frekuensi pembelian mi instan $(p<0,01)$. Sebaran frekuensi pembelian produk makanan kemasan untuk rumah tangga di wilayah perkotaan dan wilayah perdesaan disajikan pada Tabel 4.

Tabel 3 Sebaran jenis makanan kemasan yang dikonsumsi oleh rumah tangga berdasarkan lokasi geografis

\begin{tabular}{lrrrr}
\hline $\begin{array}{l}\text { Jenis produk } \\
\text { makanan } \\
\text { kemasan }\end{array}$ & \multicolumn{2}{c}{ Perkotaan } & \multicolumn{2}{c}{ Perdesaan } \\
\cline { 2 - 5 } & $\mathrm{n}$ & \multicolumn{1}{c}{$\%$} & \multicolumn{1}{c}{$\%$} \\
\hline $\begin{array}{l}\text { Susu dan } \\
\text { Olahannya }\end{array}$ & 39 & 97,5 & 34 & 85,0 \\
Makanan ringan & 36 & 90,0 & 34 & 85,0 \\
Makanan kaleng & 14 & 35,0 & 19 & 47,5 \\
Makanan bayi & 3 & 7,5 & 4 & 10,0 \\
Mi instan & 40 & 100,0 & 40 & 100,0 \\
\hline
\end{tabular}

Keterangan:

$\mathrm{n}=$ Jumlah; $\%=$ Persentase
Tabel 4 Sebaran frekuensi pembelian produk makanan kemasan per bulannya (\%)

\begin{tabular}{|c|c|c|c|}
\hline $\begin{array}{l}\text { Jenis produk } \\
\text { makanan } \\
\text { kemasan }\end{array}$ & $\begin{array}{c}\text { Tidak } \\
\text { pernah }\end{array}$ & $1-15 x$ & $16-30 x$ \\
\hline \multicolumn{4}{|c|}{ Wilayah perkotaan } \\
\hline $\begin{array}{l}\text { Susu dan } \\
\text { olahannya }\end{array}$ & 2,5 & 92,5 & 5,0 \\
\hline Makanan ringan & 10,0 & 82,5 & 7,5 \\
\hline Mi instan & 0,0 & 90,0 & 10,0 \\
\hline \multicolumn{4}{|c|}{ Wilayah Perdesaan } \\
\hline $\begin{array}{l}\text { Susu dan } \\
\text { olahannya }\end{array}$ & 15,0 & 65,0 & 20,0 \\
\hline Makanan ringan & 15,0 & 65,0 & 20,0 \\
\hline Mi instan & 0,0 & 70,0 & 30,0 \\
\hline
\end{tabular}

Pengeluaran untuk makanan kemasan. Tabel 5 menunjukkan pengeluaran rumah tangga untuk membeli makanan kemasan setiap bulannya. Tidak ada rumah tangga di perdesaan dengan total pengeluaran perkapita makanan kemasannya termasuk dalam kategori tinggi dan sedang. Pengeluaran per kapita per bulan makanan kemasan rumah tangga di wilayah perdesaan seluruhnya $(100,0 \%)$ termasuk dalam kategori rendah. Sebagian besar $(80,0 \%)$ rumah tangga di wilayah perkotaan juga mengeluarkan biaya perkapita dengan kategori rendah untuk membeli makanan kemasan. Hasil uji beda menunjukkan terdapat perbedaan yang signifikan $(p<0,01)$ pada pengeluaran per kapita untuk makanan kemasan di wilayah perdesaan dan perkotaan. Sebaran kategori pengeluaran total pembelian makanan kemasan rumah tangga di wilayah perkotaan dan perdesaan disajikan pada Tabel 5.

Tabel 5 Sebaran kategori pengeluaran total pembelian makanan kemasan rumah tangga (Rp/kap/bulan) berdasarkan lokasi geografis

\begin{tabular}{|c|c|c|c|c|}
\hline \multirow{2}{*}{ Kategori } & \multicolumn{2}{|c|}{ Perkotaan } & \multicolumn{2}{|c|}{ Perdesaan } \\
\hline & $\mathrm{n}$ & $\%$ & $\mathrm{n}$ & $\%$ \\
\hline $\begin{array}{l}\text { Rendah (2.250- } \\
\text { 142.611) }\end{array}$ & 32 & 80,0 & 40 & 100,0 \\
\hline $\begin{array}{l}\text { Sedang } \\
(142.612- \\
282.972)\end{array}$ & 5 & 12,5 & 0,0 & 0,0 \\
\hline $\begin{array}{l}\text { Tinggi } \\
(282.973- \\
423.333) \\
\end{array}$ & 3 & 7,5 & 0,0 & 0,0 \\
\hline $\begin{array}{l}\text { Minimum- } \\
\text { Maksimum }\end{array}$ & \multicolumn{2}{|c|}{$7.000-423.333$} & \multicolumn{2}{|c|}{$2.250-111.666$} \\
\hline $\begin{array}{l}\text { Rata-rata } \pm \\
\text { Standar deviasi }\end{array}$ & \multicolumn{2}{|c|}{$112.290 \pm 91.915$} & \multicolumn{2}{|c|}{$32.007 \pm 23.013$} \\
\hline$p$-value & \multicolumn{4}{|c|}{$0,000^{* *}$} \\
\hline
\end{tabular}




\section{Hubungan Karakteristik Keluarga dan Nilai Konsumen dengan Perilaku Pembelian}

Hasil uji korelasi Pearson memperlihatkan adanya hubungan signifikan negatif antara besar keluarga dengan nilai konsumen $(r=-$ $0,285, p=0,10$ ). Selain itu, terdapat hubungan signifikan positif antara lama pendidikan suami dengan nilai konsumen $(r=0,229, \quad p<0,05)$. Artinya, semakin banyak jumlah anggota keluarga maka semakin rendah nilai konsumen dan semakin tinggi pendidikan suami semakin tinggi nilai konsumennya. Tipe konsumen juga memiliki hubungan signifikan positif dengan lama pendidikan suami $(r=0,272, p<0,05)$ dan lama pendidikan istri $(r=0,383, p<0,01)$. Tipe konsumen juga berhubungan signifikan positif dengan pendapatan keluarga $(r=0,251, p<0,05)$, dan pengeluaran keluarga $(r=0,244, p<0,05)$. Artinya, semakin tinggi lama pendidikan suami dan istri, serta semakin tinggi pendapatan keluarga, dan pengeluaran keluarga maka semakin aktif tipe konsumennya.

Pengeluaran makanan kemasan memiliki hubungan signifikan positif dengan lama pendidikan suami $(r=0,422, \quad p<0,01)$, lama pendidikan istri $(r=0,478, p<0,01)$, pendapatan keluarga $(r=0,336, p<0,01)$ dan pengeluaran keluarga $(r=0,246, \quad p<0,05)$. Hal ini berarti semakin tinggi pendidikan suami dan pendidikan istri, semakin tinggi pendapatan dan pengeluaran keluarga, semakin tinggi juga pengeluaran makanan kemasannya. Selain itu, terdapat hubungan signifikan positif antara nilai konsumen dengan total pengeluaran untuk makanan kemasan $(r=0,335, p<0,01)$. Hal ini berarti semakin tinggi nilai konsumen maka akan semakin besar pengeluaran makanan kemasannya.

\section{Pengaruh Karakteristik Keluarga dan Nilai Konsumen terhadap Tipe Konsumen}

Tabel 6 menunjukkan hasil uji regresi logistik faktor-faktor yang memengaruhi tipe konsumen. Model ini menghasilkan koefisien determinasi (Nagelkekre $R$ Square) sebesar 0,445 , yang berarti 44,5 persen tipe konsumen dapat dijelaskan oleh peubah yang ada dalam model dan 56,5 persen sisanya dijelaskan oleh peubah lainnya. Lama pendidikan berpengaruh signifikan positif terhadap tipe konsumen. Semakin tinggi pendidikan maka peluang untuk memiliki tipe konsumen aktif 68,4 kali lebih tinggi. Pengeluaran keluarga juga berpengaruh signifikan positif terhadap tipe konsumen yang berarti semakin tinggi pengeluaran total keluarga, peluang untuk memiliki tipe konsumen aktif satu kali lebih tinggi.
Tabel 6 Koefisien regresi untuk analisis pengaruh karakteristik keluarga dan nilai konsumen terhadap tipe konsumen

\begin{tabular}{|c|c|c|c|}
\hline \multirow{2}{*}{ Variabel } & \multicolumn{3}{|c|}{ Tipe konsumen } \\
\hline & $B$ & $\operatorname{Exp}(B)$ & Sig. \\
\hline $\begin{array}{l}\text { Usia responden } \\
\text { (tahun) }\end{array}$ & 0,000 & 1,00 & $0,990^{*}$ \\
\hline $\begin{array}{l}\text { Besar keluarga } \\
\text { (orang) }\end{array}$ & 0,250 & 1,283 & $0,460^{*}$ \\
\hline $\begin{array}{l}\text { Lokasi } \\
\text { geografis } \\
\text { (1=perkotaan, } \\
0=\text { perdesaan }\end{array}$ & $-1,658$ & 0,191 & $0,258^{*}$ \\
\hline $\begin{array}{l}\text { Lama } \\
\text { pendidikan } \\
\text { (tahun) }\end{array}$ & 0,379 & 1,461 & $0,069^{\star}$ \\
\hline $\begin{array}{l}\text { Pendapatan } \\
\text { keluarga } \\
\text { (Rp/kap/bulan) }\end{array}$ & 0,000 & 1,000 & $0,800^{\star}$ \\
\hline $\begin{array}{l}\text { Pengeluaran } \\
\text { keluarga } \\
\text { (Rp/kap/bulan) }\end{array}$ & 0,000 & 1,000 & $0,089^{\star}$ \\
\hline Nilai konsumen & 0,155 & 0,000 & $0,334^{*}$ \\
\hline $\begin{array}{l}\text { Nagelkerke } R \\
\text { Square }\end{array}$ & & $0,445^{\star * *}$ & \\
\hline Sig. & & $0,000^{* * *}$ & \\
\hline
\end{tabular}

${ }^{*}$ Signifikan pada $p<0,01,{ }^{* * *}$ Signifikan pada $p<0,01$

\section{Pengaruh Karakteristik Keluarga, Nilai Konsumen dan Tipe Konsumen terhadap Frekuensi Pembelian Makanan Kemasan}

Model untuk menganalisis pengaruh karakteristik keluarga, nilai konsumen, dan tipe konsumen terhadap frekuensi pembelian makanan kemasan disajikan pada Tabel 7 . Model ini memiliki koefisien determinasi sebesar 0,115 (susu dan olahannya), 0,203 (makanan ringan), dan 0,158 (mi instan). Nilai ini menunjukkan bahwa perubahan variabel yang ada dalam model hanya mampu menjelaskan frekuensi pembelian makanan kemasan sebesar 11,5 persen untuk susu dan olahannya, 20,3 persen untuk makanan ringan, dan 15,8 persen untuk mi instan. Hasil uji regresi linear berganda menunjukkan bahwa faktor yang memengaruhi frekuensi pembelian produk susu dan olahannya secara signifikan adalah lama pendidikan istri $(\beta=-0,515, p<0,01)$ dan pengeluaran untuk makanan kemasan $(\beta=0,244, \quad p<0,1)$, sedangkan faktor yang memengaruhi frekuensi pembelian makanan ringan adalah usia istri $(\beta=-0,293, p<0,05)$, besar keluarga $(\beta=0,292, \quad p<0,05)$, lama pendidikan istri $(\beta=-0,430, \quad p<0,05)$ dan pendapatan keluarga $(\beta=-0,271, p<0,1)$. Selain itu, faktor yang memengaruhi frekuensi pembelian $\mathrm{mi}$ instan adalah besar keluarga $(\beta=0,215, p<0,1)$. 
Tabel 7 Koefisien regresi untuk analisis pengaruh karakteristik keluarga, nilai konsumen dan tipe konsumen terhadap frekuensi pembelian makanan kemasan

\begin{tabular}{|c|c|c|c|}
\hline \multirow{2}{*}{$\begin{array}{l}\text { Variabel } \\
\text { independen }\end{array}$} & \multicolumn{3}{|c|}{$\beta$} \\
\hline & $\begin{array}{l}\text { Susu dan } \\
\text { olahannya }\end{array}$ & $\begin{array}{c}\text { Makanan } \\
\text { ringan }\end{array}$ & $\begin{array}{c}\mathrm{Mi} \\
\text { instan }\end{array}$ \\
\hline $\begin{array}{l}\text { Usia istri } \\
\text { (tahun) }\end{array}$ & 0,115 & $-0,293^{* *}$ & $-0,080$ \\
\hline $\begin{array}{l}\text { Besar keluarga } \\
\text { (orang) }\end{array}$ & 0,140 & $0,292^{\star *}$ & $0,215^{\star}$ \\
\hline $\begin{array}{l}\text { Lama pen- } \\
\text { didikan istri } \\
\text { (tahun) }\end{array}$ & $-0,515^{\star \star *}$ & $-0,430^{* *}$ & $-0,219$ \\
\hline $\begin{array}{l}\text { Pendapatan } \\
\text { total keluarga } \\
\text { (Rp/kap/bulan) }\end{array}$ & 0,023 & $-0,271^{*}$ & 0,223 \\
\hline $\begin{array}{l}\text { Nilai konsu- } \\
\text { men (skor) }\end{array}$ & $-0,154$ & $-0,033$ & 0,155 \\
\hline $\begin{array}{l}\text { Tipe konsu- } \\
\text { men }(0=\text { kon- } \\
\text { sumen pasif; } \\
1=\text { konsumen } \\
\text { aktif) }\end{array}$ & 0,087 & 0,184 & 0,030 \\
\hline $\begin{array}{l}\text { Pengeluaran } \\
\text { makanan } \\
\text { kemasan } \\
\text { (Rp/kap/bulan) }\end{array}$ & $0,244^{*}$ & 0,055 & 0,077 \\
\hline $\begin{array}{l}\text { Lokasi } \\
\text { geografis } \\
\text { (0=perdesaan; } \\
1=\text { perkotaan) }\end{array}$ & 0,068 & 0,291 & $-0,194$ \\
\hline F-hitung & 2,289 & 2,257 & 2,853 \\
\hline $\operatorname{Adj} . R^{2}$ & 0,115 & 0,203 & 0,158 \\
\hline$p$-value & $0,031^{* *}$ & $0,033^{* *}$ & $0,008^{* *}$ \\
\hline
\end{tabular}

\section{PEMBAHASAN}

Secara umum, rumah tangga di perkotaan dan perdesaan sudah terbiasa membeli dan mengonsumsi produk makanan kemasan untuk memenuhi kebutuhan makanannya. Hal ini dapat terlihat dari hasil penelitian yang mana hampir seluruh rumah tangga di perkotaan membeli produk susu dan olahannya serta makanan ringan, sedangkan sebagian besar rumah tangga di perdesaan juga membeli produk tersebut. Pada jenis produk mi instan, seluruh rumah tangga di perkotaan maupun di perdesaan telah mengonsumsi mi instan setiap bulannya. Hal ini menunjukkan bahwa makanan kemasan sudah menjadi salah satu kebutuhan yang dikonsumsi oleh rumah tangga baik di perdesaan maupun di perkotaan.

Setiap orang akan memilih membeli makanan untuk alasan yang sama, salah satunya adalah manfaat untuk memenuhi nilai personal dan interpersonal (Humayun \& Hasnu, 2009).
Hasil penelitian menunjukkan bahwa pada dimensi nilai pemenuhan diri, rata-rata indeks rumah tangga di perkotaan lebih tinggi dibandingkan dengan rumah tangga di perdesaan. Hal ini disebabkan oleh kebutuhan yang berbeda pada rumah tangga di perkotaan dan perdesaan. Faktor yang dipertimbangkan dalam pembelian makanan instan adalah faktor mudah diperoleh dan waktu yang efisien dalam penyajian (Swamy, Kumar, \& Rao, 2012; Baskar, Kamaraj, \& Arunmozhi, 2013)

Selain itu, hal ini disebabkan adanya perbedaan akses dan jarak ke toko dan minimarket terdekat di perdesaan dan perkotaan. Rumah tangga di perdesaan memiliki jarak yang cukup jauh ke minimarket. Sumarwan (2011) menyatakan bahwa lokasi yang jauh dari konsumen tidak akan diminati untuk dikunjungi. Jarak rumah tangga ke minimarket terdekat di wilayah perkotaan adalah kurang dari $1 \mathrm{~km}$, sedangkan jarak rumah tangga ke minimarket di perdesaan adalah lebih dari $1 \mathrm{~km}$. Namun, dalam hal dimensi pemenuhan diri tidak ada perbedaan yang signifikan antara rumah tangga di perdesaan dan perkotaan. Sebagian besar kebutuhan pangan dapat dipenuhi dengan membeli makanan nonkemasan. Rumah tangga di wilayah perdesaan rata-rata hanya mengalokasikan 16 persen pengeluaran pangannya untuk makanan kemasan, sedangkan rumah tangga di wilayah perkotaan ratarata mengalokasikan 30,1 persen alokasi pengeluaran pangannya untuk makanan kemasan.

Pada dimensi nilai rasa aman, hasil penelitian menunjukkan adanya perbedaan yang signifikan antara rumah tangga di perdesaan dan perkotaan. Rasa aman merupakan salah satu nilai internal. Nilai rasa aman rumah tangga di perkotaan lebih baik dibandingkan di perdesaan. Rumah tangga di perkotaan akan lebih memilih makanan kemasan yang aman dan terjamin kualitasnya untuk dikonsumsi dibandingkan rumah tangga di perdesaan.

Tipe konsumen tergolong pada dua jenis tipe yaitu konsumen aktif dan konsumen pasif. Konsumen aktif akan mencari sebanyak mungkin informasi agar dapat membuat keputusan secara sadar dan sengaja, sedangkan konsumen pasif adalah yang tidak mencari informasi dan hanya memiliki sedikit alasan yang sadar dalam pengambilan keputusannya (Cioffi dan Garner 1996). Responden di perkotaan sebagian besar tergolong pada konsumen yang aktif namun terdapat beberapa responden di perdesaan yang tergolong konsumen pasif. Hal ini dapat 
disebabkan oleh tingkat pendidikan responden di perkotaan yang lebih tinggi dibandingkan responden di perdesaan. Ketika konsumen merasa lebih percaya mengenai kemampuan mereka untuk menilai produk, mereka biasanya akan memperoleh lebih banyak informasi. Selain itu, dengan banyaknya akses pada toko makanan kemasan terdekat di perkotaan, akan memberikan pilihan produk yang lebih bayak dibandingkan dengan wilayah perdesaan.

Lebih dari separuh rumah tangga di perkotaan dan perdesaan membeli produk makanan kemasan antara 1-16 kali per bulannya. Hal ini sejalan dengan penelitian Jha (2013) yang menyebutkan bahwa konsumen di perdesaan membeli produk makanan kemasan sekali dalam seminggu. Selain itu, ketersediaan produk di wilayah perdesaan menjadi faktor utama dalam perilaku pembelian konsumen di perdesaan.

Berdasarkan hasil uji hubungan, nilai konsumen berhubungan negatif dengan besar keluarga dan berhubungan positif dengan pendidikan suami. Menurut Kaze (2010), manusia tidak lahir dengan nilai yang tetap, nilai akan terbentuk dalam proses sosialisasi, dan transmisi melalui edukasi atau penurunan dari pengalaman generasi sebelumnya, grup sosial, atau dari individu ke individu. Peran utama dalam proses ini adalah adanya sosialisasi dari keluarga, institusi pendidikan dan agama, media massa, dan pemerintah. Komunikasi di dalam keluarga akan menyebabkan proses sosialisasi nilai yang berbeda-beda. Hasil penelitian menujukkan bahwa nilai konsumen berhubungan dengan total pengeluaran per kapita makanan kemasan per bulannya. Hal ini sejalan dengan penelitian Kim et al. (2002) yang menemukan bahwa nilai berhubungan dengan kebutuhan eksperimental dan dapat membuat konsumen lebih banyak menghabiskan uang untuk berbelanja.

Pada perilaku pembelian makanan kemasan, khususnya pertimbangan merek, rata-rata rumah tangga di perdesaan tidak mempertimbangkan merek dalam pembelian makanan kemasan. Namun, rata-rata rumah tangga di perkotaan akan mempertimbangkan merek khususnya dalam pembelian susu dan olahannya serta mi instan. Menurut Swamy, Kumar, dan Rao (2012), pertimbangan merek tidak diperlukan karena merek tidak selalu menjukkan rasa dan kualitas yang baik.

Retnaningsih, Parhati, dan Simanjuntak (2013) menyebutkan bahwa salah satu faktor yang memengaruhi perilaku pembelian adalah karakteristik keluarga. Aggota keluarga pembeli dapat memberikan pengaruh yang kuat terhadap perilaku pembeli. Hasil penelitian menunjukkan bahwa usia istri, lama pendidikan merupakan faktor yang berpengaruh dalam frekuensi pembelian makanan ringan dan produk susu. Hal ini sejalan dengan penelitian Retnaningsih, Parhati, dan Simanjuntak (2013) bahwa usia, lama pendidikan berpengaruh terhadap perilaku pembelian buah. Hal ini juga sejalan dengan hasil penelitian Sukmaningtyas dan Hartoyo (2013) juga menyebutkan bahwa usia memiliki pengaruh yang signifikan terhadap perilaku pembelian buah apel impor. Selain itu, besar keluarga juga merupakan faktor yang mempengaruhi frekuensi pembelian makanan kemasan. Selain itu, hasil penelitian sejalan dengan Jha (2013) yang menyatakan bahwa seiring meningkatnya besar keluarga, maka konsumsi dalam keluarga tersebut juga semakin besar.

Salah satu faktor yang memengaruhi frekuensi pembelian makanan kemasan pada produk makanan ringan adalah pendapatan total keluarga. Hasil penelitian sejalan dengan Singh (2012) yang menemukan adanya perbedaan level pendapatan pada rumah tangga dapat berpengaruh pada perbedaan pembelian pada produk lemari pendingin. Hasil penelitian mendukung hasil penelitian Leiptag dan Kaufman (2003) bahwa rumah tangga dengan pendapatan yang lebih kecil akan membelanjakan lebih sedikit uangnya dalam pembelian makanan.

Selain itu, usia responden, lama pendidikan, pendapatan keluarga dan pengeluaran total per kapita makanan kemasan juga merupakan faktor yang berpengaruh terhadap frekuensi pembelian makanan ringan dan produk susu. Hasil ini sejalan dengan penelitian Retnaningsih, Parhati dan Simanjuntak (2013) bahwa usia, lama pendidikan berpengaruh terhadap perilaku pembelian. Hasil penelitian Sukmaningtyas dan Hartoyo (2013) juga menyebutkan bahwa usia memiliki pengaruh yang signifikan terhadap perilaku pembelian buah apel impor. Selain itu, besar keluarga juga merupakan faktor yang memengaruhi frekuensi pembelian makanan kemasan. Hasil ini didukung hasil penelitian sebelumya yang menyatakan bahwa seiring meningkatnya besar keluarga, maka konsumsi dalam keluarga tersebut juga semakin besar (Jha, 2013).

Faktor yang memengaruhi frekuensi pembelian makanan kemasan adalah pendapatan keluarga. Hasil penelitian sejalan dengan Singh (2012) yang menemukan adanya perbedaan level pendapatan pada rumah tangga dapat berpengaruh pada perbedaan pembelian pada produk lemari pendingin. 
Selain itu, hal ini juga sejalan dengan hasil studi Leiptag dan Kaufman (2003) bahwa rumah tangga dengan pendapatan yang lebih kecil akan membelanjakan lebih sedikit uangnya dalam pembelian makanan.

\section{SIMPULAN DAN SARAN}

Rumah tangga di perkotaan dan perdesaan memiliki perbedaan nilai konsumen, tipe konsumen dan perilaku pembelian produk makanan kemasan. Nilai rumah tangga di perkotaan lebih baik daripada di perdesaan. Tipe konsumen di perkotaan lebih aktif dibandingkan tipe konsumen di perdesaan dan memiliki pengeluaran makanan kemasan lebih besar dibandingkan dengan di perdesaan. Jenis makanan kemasan yang dibeli oleh rumah tangga sebagian besar adalah produk susu dan olahannya, makanan ringan dan mi instan. Semakin tinggi lama pendidikan suami, maka semakin tinggi nilai konsumen, sedangkan semakin besar keluarga semakin rendah nilai konsumennya. Tipe konsumen memiliki hubungan dengan lama pendidikan istri dan suami, pendapatan serta pengeluaran total keluarga. Semakin tinggi pendidikan suami istri, semakin besar pendapatan dan pengeluaran keluarganya, semakin aktif tipe konsumennya. Nilai konsumen juga memiliki hubungan dengan pengeluaran makanan kemasan. Faktor-faktor yang memengaruhi frekuensi pembelian makanan kemasan adalah usia, lama pendidikan, besar keluarga, serta pendapatan total keluarga.

Penelitian ini dilakukan terhadap beberapa produk makanan kemasan yang dikonsumsi oleh keluarga. Oleh karena itu, penelitian selanjutnya disarankan mengkhususkan hanya pada salah satu produk makanan kemasan saja. Penelitian tipe dan nilai konsumen juga diharapkan lebih banyak untuk dilakukan karena kurangnya penelitian dalam hal tersebut di Indonesia. Perlu adanya pengembangan instrumen pengukuran yang berkaitan dengan nilai konsumen dan tipe konsumen. Selain itu, perlu adanya program pendidikan dari pemerintah serta instansi terkait khususnya BPSK (Badan Penyelesaian Sengketa Konsumen) yang fokus terhadap tipe konsumen pasif khususnya di perdesaan agar lebih aktif lagi untuk mencari informasi terkait produk yang akan dibeli. Bagi ibu rumah tangga sebagai pengambil keputusan pembelian produk pangan, sebaiknya lebih teliti dan memiliki informasi yang cukup sebelum melakukan pembelian.

\section{DAFTAR PUSTAKA}

Baskar, K., Kamaraj, K., \& Arunmozhi, R. (2013). A study on instan food products buying behavior of consumers in Cuddalore District. Indian Streams Researh Journal, 2(12). Diambil dari: http:// http://www.ijrct.org. [diunduh 3 Jun 2013].

[BPS] Badan Pusat Statistik. (2011). Bogor dalam Angka 2012. Bogor, ID: Badan Pusat Statistik.

Cioffi, D., \& Garner, R. (1996). "On doing the decision: effects of active versus passive choice on commitment and selfperception", Personality and Social Psychology Bulletin, 22(2), 133-47.

Homer, P. M., \& Kahle, L. R. (1998). A structural equation test of the valueattitude-behavior hierarchy. Journal of Personality and Social Psychology, 54(4), 638-46.

Humayun, K., \& Hasnu, S. (2009). An analysis of consumer values, needs and behavior for liquid milk in hazara, pakistan. Proceeding $2^{\text {nd }}$ CBRC, Pakistan, 2. Diambil dari http://www.ciitlahore.edu.pk/pl/abrc/Procee dings/. [diunduh 3 Jun 2013].

Jha, M. (2013). Buying behavior of rural consumer with reference to packaged food product in Bihar. International Journal of Management Research and Review, 3(11).

(2013). A study on rural buying behavior in Bihar. International Journal of Marketing, Financial Service \& Management Resesarch, 2(2).

Kaze, V. (2010). The impact of customer values on purchasing behavior: A case on Latvian insurance market. Journal Economic and Management, 15.

Kim, J. O., Forsythe, S., Gu, Q., \& Moon, S. J. (2002). Cross-cultural consumer values, needs and purchase behavior. The Journal of Consumer Marketing, 19(6).

Leiptag, E. S., \& Kaufman, P. R. (2003). Exploring food purchase of low-income household, how do the economize? Agriculture Information Bulletine, 747.

McGregor, S. L. T. (2010). Consumer Education as a site of political resitance: 50 years of conceptual evolution. Diambil dari www.consultmcgregor.com. [ diunduh 12 Mar 2013]. 
Retnaningsih, Parhati, R., \& Simanjuntak, M. (2013). Analisis perilaku pembelian buah di perdesaan dan perkotaan. Jur. IIm. Kel. \& Kons., 6(2). 127-136.

Roos, I., \& Gustafsson, A. (2011). The influence of active and passive customer on switching in customer relationship. Managing Service Quality. 21(5).

Singh J. (2012). Influence on rural and urban consumer buying. Global Journal of Management and Business Research. 12(7).

Sukmaningtyas, A., \& Hartoyo. (2013). Pengaruh nilai dan gaya hidup terhadap preferensi dan perilaku pembelian buahbuahan impor . Jur. IIm. Kel. \& Kons., 6(1), 39-48.

Sumarwan, U. (2011). Perilaku konsumen teori penerapannya dalam pemasaran. Bogor, ID: Ghalia Indonesia.

Swamy, M. B., Kumar, T. A., \& Rao, K. S. (2012). Buying behavior of consumer towards instant food product. International Journal of Research Computational Technology, 2(2). Diambil dari http:// www.ijrct.org/documents/1000006.pdf. [diunduh 3 Jun 2013]. 